Archived version from NCDOCKS Institutional Repository http://libres.uncg.edu/ir/asu/

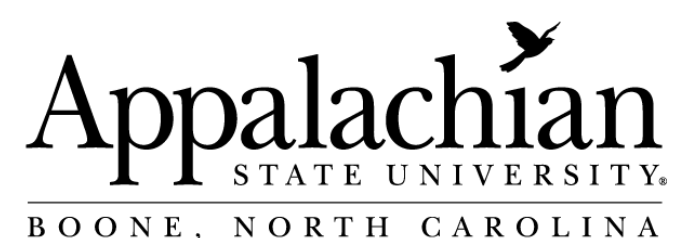

B O O N E, N O R T H C A R O I N A

\title{
Shared Decision-Making: Case Study Analysis to Promote Cross-Program Dialogue between Administrators and Media Coordinators
}

By: Robert L. Sanders, Roma B. Angel

\begin{abstract}
There is a general lack of cross-course and cross-programme dialogue in US colleges of education. Few, if any, opportunities are provided to engage graduate students in authentic dialogue about real school problems and issues. A grant-funded initiative has been launched at Appalachian State University to utilise case studies and web based communication tools to create authentic learning environments that support interaction between school administration and library science students to discuss real school problems and develop lasting solutions. This paper discusses a research study in which case study analysis was used to promote online cross-programme dialogue and assist students in developing their professional voice.
\end{abstract}

Sanders, Robert \& Angel, Roma. (2007). Shared decision-making: Case study analysis to promote cross-programme dialogue between administrators and media coordinators, International Journal of Web Based Communities, 3(2), 206-218. Published by Interscience. (ISSN: 1477-8394) DOI: 10.1504/IJWBC.2007.014081 
Sanders, R.L. \& Angel, R.B. (2007). Shared decision-making: Case study analysis to promote cross-programme dialogue between administrators and media coordinators, International Journal of Web Based Communities, 3(2), 206-218. Published by Interscience. (ISSN: 1477-8394) DOI: 10.1504/IJWBC.2007.014081

\title{
Shared Decision-Making: Case Study Analysis to Promote Cross-Program Dialogue between Administrators and Media Coordinators
}

\author{
Robert L. Sanders \\ Appalachian State University \\ Boone, NC USA \\ sandersrl@appstate.edu \\ Roma B. Angel \\ Appalachian State University \\ Boone, NC USA \\ angelrb@appstate.edu
}

\begin{abstract}
There is a general lack of cross-course and cross-programme dialogue in US colleges of education. Few, if any, opportunities are provided to engage graduate students in authentic dialogue about real school problems and issues. A grant-funded initiative has been launched at Appalachian State University to utilise case studies and web based communication tools to create authentic learning environments that support interaction between school administration and library science students to discuss real school problems and develop lasting solutions. This paper discusses a research study in which case study analysis was used to promote online cross-programme dialogue and assist students in developing their professional voice.
\end{abstract}




\section{INTRODUCTION}

The focus of this paper is on building solution communities of school leaders who are committed to building systems in which the pressing multidimensional problems facing public schools are addressed collaboratively. For this work to positively affect public schools and have a lasting effect upon school culture, graduate students must experience the practice of shared decisionmaking and develop a leadership voice through their commitment to the work of involving all stakeholders in solution processes.

There seems to be a lack of authentic communication among professionals from differing content disciplines and across grade levels. At the university we often encounter graduate students who appear to be more interested in acquiring checklists for doing their work than those who want to build learning connections based on the researched knowledge of the field. Living and working in positive microcosmic and macrocosmic environments depend upon the ability to communicate about essential issues and relationships in life.

Likewise, there is a general lack of cross-course and cross-program dialogue in colleges of education; program areas remain distinct and separate from one another, promoting programspecific purposes with little regard for analysis of the purposes of others. Few, if any, opportunities are provided to engage students in authentic dialogue about real school problems and issues. This lack of cross-program dialogue in graduate studies reinforces the notion that stakeholder groups should not communicate or collaborate to solve school issues in the practice of their profession.

In particular, there is a belief held by many school media coordinators that administrators do not fully appreciate the role of the media coordinator. As such, coordinators often feel undervalued, marginalized, and unappreciated. Through interviews with practicing media coordinators and principals, graduate students in school media often discover that neither completely understands the other, nor is either aware of the driving forces that guide what each does and the decisions each makes. These students also realize that there is a lack of communication between the principals and media coordinators, which appears to be a reason, if not the reason, for this breakdown in what could be a positive relationship.

It is the goal of our graduate level education programs at Appalachian State University to empower students to be active participants in shared leadership and decision-making. All educators, regardless of position or responsibilities, need to develop a professional and political voice with which to articulate their perspectives related to the decisions made concerning leadership, teaching, and learning. Unfortunately, educators often find that communication does not occur among various stakeholder groups and that school decision-making is limited to a select few.

It is our goal in the college of education to develop solution communities to facilitate and encourage these important cross-program discussions and to provide opportunities to learn about the perspective of others with whom education professionals will work. Providing safe environments in which graduate students can analyze and discuss the crucial issues of school is crucial to identifying potential solutions and to develop their own professional voices as they learn to work together (Hanson \& Hanson, 2000; Hoy \& Tarter, 1995; Kirschmann, 1995; Kowalski, 1998, 2001; Merseth, 1997; Northouse, 2001; Sharp, 1997; Snowden \& Gorton, 2002).

A grant-funded initiative has been launched at Appalachian State University to utilize web-based instruction that calls upon case studies and discussion boards for the development of real and 
virtual learning communities. These online communities can create the necessary opportunities for programs to model and engender collaboration between graduate students and to facilitate student discourse to enhance the process of shared, creative problem solving. Case studies are analyzed by like groups of students using the "Learning School Leadership Praxis through Case Studies" tool prepared by Angel (2004) (Appendix A).

Ultimately, the focus of this grant has been to create an authentic learning environment that supports interaction between school administration and library science students and helps to answer the question: How can graduate program faculty influence school leaders to talk with other educators across all grade levels and disciplines about school problems and lasting solutions?

\section{REVIEW OF THE LITERATURE}

Little effort is required to locate the literature on the perceptions administrators have of school library media specialists and on the subsequent relations these educators have with one another. A significant number of articles have been written by both media specialists and administrators on various themes related to these perceptions, providing some explanations, discussing resulting harms, and suggesting the importance for improved relations. A review of the more recent literature reveals five primary themes: Misperceptions, Leadership, Education, Advocacy, and Value.

\section{MISPERCEPTIONS}

It is agreed upon by most researchers that school decision makers such as principals do not fully understand what media specialists do (Alexander, Smith, \& Carey, 2003; Anderson, 1998; Frost, 2005; Hartzell, 2002; Kachel, 2003; O’Neal, 2004; Sanders, 2002; St. Lifer, 2004; Williams, 2006). The media specialist is simply seen as a resource person rather than as a school leader (Williams, 2006). This perception marginalizes the media specialist, thus limiting his or her ability to make a positive contribution in the school. The principal does not recognize the media specialist as an instructional leader in the school, nor does s/he understand the potential of having such a person on their staff (Frost, 2005).

Principals need to see media specialists engaged in collaboration and teaching. Anderson (1998) asserts that media specialists should not assume that principals understand the role of the media specialist and that principals will assume that the media specialist's job is clerical if $\mathrm{s} / \mathrm{he}$ is observed doing clerical tasks. They fail to recognize the impact that the media program has on academic achievement (O'Neal, 2004) or the depth, breadth, and importance of the media specialist in the planning and collaboration that is done with classroom teachers (Hartzell, 2002). Since it is difficult to distinguish how much of a student's success can be attributed to the efforts of the media coordinator and how much to the teacher, student success is generally attributed to the teacher even when the media specialist has played a very direct role in instruction. The principal only knows how to recognize successful teaching, which means the teacher often receives most if not all of the credit (Hartzell, 2002). 


\section{LEADERSHIP}

Research supports the logical belief that the principal is a leader in the school and has the power to influence teachers' perceptions of the media program and the school media specialist (Alexander, Smith, \& Carey, 2003; Harvey, 2005; Moghee, 2005; O’Neal, 2004; Sanders, 2002; St. Lifer, 2004). Harvey (2005) points out that the principal's attitude about the media specialist and the overall media program has a significant impact on the teachers' perceptions of both. Teachers pay attention to those things about which a principal is passionate (St. Lifer, 2004). If the principal is passionate about the media program and views the media coordinator as a teacher and the media program as the heart of the school (Sanders, 2002), the teachers in school will follow suit. Ultimately, it comes down the principal in deciding between a media center that is simply a resource center vs. one that is central to the instructional activities of the school. McGhee and Janson (as cited in Moghee, 2005) argue, "But they [school media specialists] don't have the time to make the library media center central to teaching and learning. It takes steadfast and knowledgeable leaders to change this detachment to powerful collaboration" (p. 63). In other words, it is the responsibility of the principal to support and promote the media program as the cornerstone of the instructional program.

\section{EDUCATION}

Not surprisingly, school administrators receive little, if any, instruction regarding the role or value of the school media center (Alexander, Smith, \& Carey, 2003; Frost, 2005; Hartzell, 2002; Kachel, 2003; Moghee, 2005; O'Neal, 2004; Wilson \& Blake, 1993). While there seems to be a need for school administration programs to integrate units related to the school media program (O'Neal, 2004), few programs offer any such overview or instruction. Even when these issues are discussed in the literature or occasionally addressed in school administration graduate courses, there is very little in terms of prescribing strategies for effective partnerships between media specialists and administrators (Alexander, Smith, \& Carey, 2003). Interestingly, these researchers put the responsibility on library media programs to initiate these partnerships, arguing that, "Principals need to be educated about what we do. The change agents should be library media educators in colleges and universities, who should initiate collaboration with the programs that prepare school administrators" (p. 13). Wilson and MacNeil (1998) add that principal preparation programs should also take responsibility for exposing pre-service principals to the value of media programs rather than allowing them to maintain stereotypes or misconceptions based on their memories of media coordinators when they were students (Frost, 2005).

\section{ADVOCACY}

Researchers suggest that media specialist address principals' lack of formal instruction noted above by becoming advocates for themselves and for their programs (Frost, 2005; O'Neal, 2004; St. Lifer, 2004; Williams, 2006; Wilson \& Blake, 1993). There are few others who understand or value the library media program in the same way the media specialist does. They must, therefore, be the first to stand up to advocate for their programs (Williams, 2006). Teachers and administrators have misconceptions of what the media specialist does (as noted above) or what value the media program has in terms of student achievement (as noted below). St. Lifer (2004) argues, “Some [librarians] don't advocate well, they don't see that they need to promote and sell their role as instructional leaders, but rather see themselves as just a support function to provide resources where needed" (p. 11). O'Neal (2004) adds that media specialists 
are simply not informing teachers and principals of the contributions they are making in the school. Media specialists must therefore take the initiative to speak up for themselves and their programs by educating these colleagues about the work they do and the value they bring to the school as instructional leaders (Frost, 2005).

\section{VALUE}

Ultimately, it is essential that the principal and the media specialist learn to work together to develop a mutually beneficial relationship. Hartzell is quoted in O'Neal (2004) stating that a quality media program can enhance student achievement and that "informed, committed librarians can help principals enhance their own administrative practice" (p. 287). While this relationship has not been addressed systematically, its value is clear and can be considered a vital ingredient in learning (Alexander, Smith, \& Carey, 2003). Harvey (2005) supports this in pointing out that a partnership between the principal and the media specialist is natural given that both educators work directly with every teacher in the building. For this partnership to work, however, both partners must have basic knowledge of the other along with a desire to help students achieve (Kachel, 2003). Hartzell (2002) continues this point by stating, "School efficiency and effectiveness can be improved if principals recognize and trust the resources resident in media centers and media specialists" (p. 104). In the end, all can benefit from this knowledgeable, trusting relationship.

\section{METHODOLOGY}

The study was designed to extend the research cited by the literature into the context of an interaction between two groups of graduate students who would soon be working together in a hierarchical environment that traditionally has not promoted professional dialogue to address real school issues. A survey instrument was used to collect feedback from these two groups of educators on their involvement and interactions related to the writing and sharing of the case briefs.

\section{PARTICIPANTS}

A total of 43 graduate students were surveyed. 27 of these students were completing their first semester in a graduate Library Science program (MLS Students). They were enrolled in a collection development course, taught by one author of this paper. The remaining 16 students were pursuing their graduate degrees in Curriculum and Instruction, with the goal of becoming district level Curriculum Specialists (CS Students). These students were enrolled in a Supervision course, taught by the other author of this paper.

\section{PROCEDURE}

The project began with the development of a rubric for analyzing case studies from the standpoint of school leadership (Angel, 2004). This case study analysis tool, later titled, "Learning School Leadership Praxis through Case Studies," would require students to do a careful reading of the case study, identify missing information, analyze the perspectives of the case's characters, identify the primary problem (one that if solved would prevent the 
reoccurrence of this issue) and the secondary problem(s), outline and analyze possible solutions, and develop a decisive action plan.

Dr. Angel then identified a pressing issue for public schools and wrote a case study about it. For this particular project, the case study focused on a community group's challenge of a controversial title in the school library media center's collection. Once the case study was written, students would be assigned to small groups within their own program area where they engaged in solving this case in a "solution community." It was expected that the groups would discuss issues, come to consensus, and write case briefs in these small course-alike groups. Each group would upload their brief to a threaded discussion board, read the briefs posted by other groups (from both the CS students and the MLS students), discuss the briefs using the discussion board, and later engage in full-class face-to-face dialogue about the case and their various group solutions and actions. They would then be given an opportunity to rewrite their own group's brief using ideas they gained from other groups.

\section{INSTRUMENTS}

The voluntary survey was provided to the students at the end of the face-to-face meeting of all 43 students participating in the case study project. The survey consisted of 21 questions. Seven of the questions were Yes/No questions with an opportunity for respondents to provide comments; three questions provided a checklist of responses; ten questions allowed for a Likert scale response (1-5); and, one question allowed for a short answer response. The questions solicited data regarding the students' use of communication technologies and case studies, and their assessment of the collaborative process required to complete the project.

Surveys were returned anonymously and the data was compiled in a spreadsheet format to facilitate comparisons and quantitative analysis. Totals and mean scores were determined for the entire data set. Mean scores were also determined for both groups of respondents (MLS Students and CS Students). Comments offered were transcribed and included in the spreadsheet.

\section{RESULTS}

The data suggests that the students in the CS group had stronger technology skills, more experience with the use of web-based discussion boards, and more experience using case studies. Both groups of students were satisfied with their own involvement in the discussion boards used for the project. The students perceived this board as a comfortable place to work and interact (Figure 1). In general, each group of students seemed to enjoy the opportunity to interact with the other group of students but were aware that the posts were public and that an audience other than one's own classmates must be considered at all times. 


\begin{tabular}{|l|l|l|l|}
\hline Question & Total Response & MLS Response & $\begin{array}{l}\text { Curr. Spec. } \\
\text { Response }\end{array}$ \\
\hline $\begin{array}{l}\text { Rate OWN Technology } \\
\text { Skills (1-5: Novice - Expert) }\end{array}$ & 3.5 & 3.3 & 3.9 \\
\hline $\begin{array}{l}\text { Prior Experience with web } \\
\text { discussion board (Y or N) }\end{array}$ & -- & $44.4 \%$ Yes & $93.8 \%$ Yes \\
\hline $\begin{array}{l}\text { Rate OWN experience with } \\
\text { this board (1-5: Frustrating - } \\
\text { Very Satisfying) }\end{array}$ & 3.8 & 3.8 & 3.9 \\
\hline $\begin{array}{l}\text { Discussion Board as } \\
\text { comfortable place }\end{array}$ & -- & $92.6 \%$ Yes & $87.5 \%$ Yes \\
\hline $\begin{array}{l}\text { Prior Experience with case } \\
\text { studies }\end{array}$ & -- & $37 \%$ Yes & $56.3 \%$ Yes \\
\hline
\end{tabular}

Figure 1: Experience with Technology and Case Studies

Students were first required to work in course-alike groups to read, discuss, and collaboratively develop a case brief to serve as their collective response to the issues raised in the shared case study. Most students in both groups used email and face-to-face interactions to collaborate with their course-alike group members. Discussion boards were also used, but to a lesser extent. Some students used the telephone to interact and collaborate with their peers. No other tools were reported to have been used (including but not limited to Instant Messaging or chat).

The MLS groups and the CS groups took a similar approach to the collaborative process. Both MLS and CS students reported that in nearly half the course-alike groups discussed the case but assigned one student to actually write the final case brief. In the remaining course-alike groups, the students divided the work and wrote their assigned section of the brief. In some cases, all students in the groups served as editors for what the other(s) had written. One significant difference between the MLS and the CS groups appeared in their respective use of the appendices and charts provided in the "Learning School Leadership Praxis through Case Studies" analysis tool. More than half of the MLS students reported to have used these additional tools. Only about $6 \%$ of the CS students reported to have used them. Ultimately, both types of student respondents reported a high level of collaboration, consensus, and participation in their course-alike project groups (Figure 2). 


\begin{tabular}{|l|l|l|}
\hline Question & MLS Response & $\begin{array}{l}\text { Curr. Spec. } \\
\text { Response }\end{array}$ \\
\hline $\begin{array}{l}\text { Collaboration Methods in } \\
\text { Course Alike groups }\end{array}$ & & \\
\hline Email & $92.6 \%$ & $87.5 \%$ \\
\hline IM & $0 \%$ & $0 \%$ \\
\hline Phone & $22.2 \%$ & $6.3 \%$ \\
\hline Discussion Boards & $44.4 \%$ & $43.8 \%$ \\
\hline Chat & $0 \%$ & $0 \%$ \\
\hline F2F & $88.9 \%$ & $81.3 \%$ \\
\hline Other & $0 \%$ & $0 \%$ \\
\hline Process of Course Alike groups & $44.4 \%$ & $56.3 \%$ \\
\hline Divided work & $55.6 \%$ & $50 \%$ \\
\hline All discussed-one wrote & $0 \%$ & $0 \%$ \\
\hline One student did all work & $37 \%$ & $43.8 \%$ \\
\hline All served as editors & $51.9 \%$ & $6.3 \%$ \\
\hline $\begin{array}{l}\text { Used the Learning Praxis } \\
\text { appendices and charts }\end{array}$ & 4.5 & 4.4 \\
\hline $\begin{array}{l}\text { Rate Consensus in Course } \\
\text { Alike group (1-5: low - high) }\end{array}$ & 4.3 & 4.1 \\
\hline $\begin{array}{l}\text { Rate Collaboration in Course } \\
\text { Alike group (1-5: low - high) }\end{array}$ & 4.3 & \\
\hline
\end{tabular}

Figure 2: Collaboration in Course Alike Groups

All students believed the case scenario to be an accurate portrayal of something that might take place in a real school setting. They also indicated that their own perspectives and those of the other students participating in the project were accurate in terms of understanding and analyzing the case (Figure 3).

\begin{tabular}{|l|l|l|l|}
\hline Question & Total Response & MLS Response & $\begin{array}{l}\text { Curr. Spec. } \\
\text { Response }\end{array}$ \\
\hline $\begin{array}{l}\text { Rate quality of collaboration } \\
\text { and consensus between both } \\
\text { groups of students (1-5: low - } \\
\text { high) }\end{array}$ & 4.1 & 4.0 & 4.3 \\
\hline $\begin{array}{l}\text { Rate student's OWN } \\
\text { participation in responding to } \\
\text { briefs (1-5: low - high) }\end{array}$ & 4.2 & 4.1 & 4.3 \\
\hline $\begin{array}{l}\text { Rate Accuracy of scenario (1- } \\
\text { 5: inaccurate - accurate) }\end{array}$ & 4.5 & 4.4 & 4.7 \\
\hline $\begin{array}{l}\text { Rate Accuracy of perspectives } \\
\text { of course specific groups (1-5: } \\
\text { inaccurate - accurate) }\end{array}$ & & & 4.5 \\
\hline Library Science & 4.3 & 4.2 & 4.6 \\
\hline Curr. Spec. & 4.3 & 4.1 & \\
\hline
\end{tabular}

Figure 3: Perceptions of Collaboration and Consensus Between Groups 
Regarding students' own participation in the case study discussion boards, MLS students reported asking more questions, agreeing and disagreeing more with students, offering more examples, and elaborating more on the ideas of others than their CS counterparts. Neither group reported any significant attempts to persuade others of their own way of thinking. $66.7 \%$ of MLS students reported that the meeting helped to alter their opinion in the case compared to $81.3 \%$ of the CS students. Both groups reported that the multi-program group experience was valuable or very valuable and that the interactions between these two larger groups of students helped them understand different perspectives held by others in the school setting. Students indicated that they now feel more comfortable with shared decision-making and more confident in leading the implementation of a shared decision-making process in their own schools.

Overall, student respondents rated the overall project as valuable or very valuable and commented that the project was a beneficial, eye-opening experience that allowed students to examine real school issues from a variety of perspectives (Figure 4).

\begin{tabular}{|c|c|c|c|}
\hline Question & $\begin{array}{l}\text { Total } \\
\text { Response }\end{array}$ & MLS Response & $\begin{array}{l}\text { Curr. Spec. } \\
\text { Response }\end{array}$ \\
\hline \multicolumn{4}{|l|}{$\begin{array}{l}\text { Characterization of OWN } \\
\text { participation }\end{array}$} \\
\hline Ask questions & -- & $81.5 \%$ & $68.8 \%$ \\
\hline Agreed with students & -- & $96.3 \%$ & $81.3 \%$ \\
\hline Disagreed with students & -- & $92.6 \%$ & $37.5 \%$ \\
\hline Offered examples & -- & $74.1 \%$ & $31.3 \%$ \\
\hline Elaborated on ideas & -- & $74.1 \%$ & $56.3 \%$ \\
\hline Attempted to convince others & -- & $22.2 \%$ & $18.8 \%$ \\
\hline Other & -- & $\begin{array}{l}\text { Offered different (new) } \\
\text { perspective }\end{array}$ & \\
\hline $\begin{array}{l}\text { Rate experience of working in } \\
\text { Multi-program groups (1-5: } \\
\text { waste - very valuable) }\end{array}$ & 4.5 & 4.4 & 4.6 \\
\hline $\begin{array}{l}\text { Help in understanding different } \\
\text { perspectives? }\end{array}$ & -- & $96.3 \%$ Yes & $100 \%$ Yes \\
\hline $\begin{array}{l}\text { Alter opinion as a result of } \\
\text { meeting? }\end{array}$ & -- & $66.7 \%$ Yes & $81.3 \%$ Yes \\
\hline $\begin{array}{l}\text { Help you feel more } \\
\text { comfortable with shared } \\
\text { decision-making? }\end{array}$ & -- & $96.3 \%$ Yes & $93.8 \%$ Yes \\
\hline $\begin{array}{l}\text { Help you confident in } \\
\text { implementing shared decision- } \\
\text { making process? }\end{array}$ & -- & $96.3 \%$ Yes & $100 \%$ Yes \\
\hline Rate project overall & 4.5 & 4.4 & 4.6 \\
\hline
\end{tabular}

Figure 4: Overall Reactions to Project Participation

\section{DISCUSSION}

Some of the differences between the two groups of students (i.e. difference in technology skills, prior use of case studies, and in particular, prior use of discussion boards) revealed through the survey could be attributed to the fact that the CS students were further along in their program than the MLS students. Both groups were similar, however, in their utilization of more ubiquitous communication technologies such as email and discussion boards despite the rise in popularity 
of instant messaging and chat tools in recent years. Responses from participating students indicated that they had not yet adopted these technologies to supplement the asynchronous communication tools with which they were more familiar and comfortable.

One significant difference revealed was in the students' use of the appendices to the Learning Praxis document. Nearly half of the MLS students indicated that they used these optional tools, compared to only $6.3 \%$ of the CS students. This difference might be attributed to how the respective faculty instructor introduced and explained the assignment to their students. It should be noted that neither group was required to use these tools but because the tools were developed by the faculty member working directly with the CS students, one might expect that these students would be have been more inclined to use the tools rather than less.

It is noteworthy that the two groups characterized their own participation differently in terms of asking questions, agreeing and disagreeing with other students, offering examples, and elaborating on the ideas of others. This difference might be attributed to the fact that the MLS students were more recently admitted to graduate school and therefore more inclined to ask questions and approach new ideas with fewer assumptions. It might also be attributed to the fact that many of the MLS students have not been provided an opportunity to share their ideas or voice with those they perceive having more power in a typical school setting. Regardless of the quality of this group's participation, the MLS students' level of involvement had less impact on their own positions than on the positions held by their CS colleagues. Perhaps all the questions, challenges, and examples offered by the MLS students offered a convincing perspective on the issues that encouraged the CS students to be much more likely to change their minds about the case. It seemed that the MLS students were more confident in their proposed action plans after having worked in their course-alike groups than the CS students who appeared more inclined to consider alternative perspectives after meeting with the MLS students.

Overall, both groups of students indicated an appreciation of the opportunity for interaction, collaboration, and shared-decision making that this project provided. It provided them with a model for future work in schools where they would soon meet again and an appreciation of the varied perspectives that each stakeholder brings to the table, if invited.

\section{CONCLUSIONS}

The objectives for this project were to 1 ) encourage cross-course discussions in which students analyze and discuss the crucial issues of school to better identify potential solutions and 2) to develop their own professional voices as they learn to work together. We set out to better understand these objectives in the context of the interactions between two groups of graduate students who would soon find themselves working side by side in an authentic school environment.

We ultimately found that this activity did address these two objectives by providing a structure to support cross-course dialogue and engaging students in a safe community of problem solving. The study provided a systematic way for students enrolled in School Administration programs to learn about the value of their media colleagues, addressing O'Neal's (2004) call for such opportunities to integrate library media issues into graduate administration programs. The collaborative analysis of case studies also provided our students with a forum in which preservice media coordinators could develop a professional voice and learn to advocate for their programs and for their profession, thus changing the status quo as described by Frost (2005), 
O'Neal (2004), St. Lifer (2004), Williams (2006), and Wilson \& Blake (1993) regarding media coordinators' reluctance or inability to advocate for their positions or their programs. Our findings support the assertions of Alexander, Smith, \& Carey (2003), Harvey (2005), and Kachel (2003) regarding the value that a positive collaborative relationship between an administrator and media coordinator can result in the overall success of the school and of the media program. Our students' willingness and confidence in developing solution communities in their own schools is a positive step forward in solving real problems in these schools.

Too often instructors attempt to integrate technology for the sake of integrating technology. This project initiative, however, has been driven by a well-founded conceptual framework and by specific curricular needs that necessitated the use of technology. While the project required significant time and effort in environment development and in case preparation, the upfront work allowed the instructors to serve more as facilitators and moderators of the analyses and discussions.

We suggest that others interested in this area of online case-based instruction consider the following recommendations before attempting a similar implementation of this project. First, the case studies themselves should be developed enough that they offer a complex, multidimensional account of an authentic, potential conflict that might arise in a K-12 school environment. Second, while the case should involve multiple characters to allow the case to fully play out, none of these characters should be characterized as "bad people." There may be bad decisions made by a character but it should be established that no character is inherently bad. Finally, the focus of the project should not be on the technology tool used to support the community and facilitate the discussion but rather on students finding their voices and engaging in authentic dialogue around real problems. Technology is a mere vehicle for a more creative, and possibly real, conceptualization of school situations. It is time for creative solutions to crucial school and cultural issues.

One area of further research needed should focus on the differences between the MLS and CS students' need, desire, or ability to modify their positions on the action plans proposed. Why did the MLS students hold more strongly to their positions than the CS students? Why were the CS students more inclined to modify their own positions after their face-to-face interactions with the MLS students? Another potential area of research could examine the collaboration that was required between the two faculty involved in this project and the impact that this modeling had on their respective students. How was the students' perspective of collaborative problem solving required in this project impacted by their awareness of the collaborative relationship their faculty instructors developed through the planning and implementation of the project?

Ultimately, we want our students to continue these discussions once they enter the educational workforce. We believe that if students learn to communicate with each other now and begin to recognize that each stakeholder group possess a distinct and important set of expert skills and knowledge, that they will come to realize the benefits of collaboration outweigh the comfort and ease of unilateral decision making. This awareness can then be the foundation for the belief in shared leadership we hope to instill in our students.

\section{ACKNOWLEDGEMENTS}

The authors of this paper wish to acknowledge the support for research through the Successful Applications of Learning Technologies (SALT) grant funded by the Office of the Dean, Reich College of Education, and Appalachian State University. 


\section{REFERENCES}

Alexander, L. B., Smith, R. C., \& Carey, J. O. (2003). Education reform and the school library media specialist: Perceptions of principals. Knowledge Quest, 32(2), 10-13.

Anderson, M.A. (1998). Expectations: Building partnerships with principals. MultiMedia Schools, 5(5), 26-28.

Angel, R.B. (2004). Learning school leadership praxis through case studies. Unpublished Manuscript.

Frost, C. (2005). Leadership: Library leaders: Your role in the professional learning community. Knowledge Quest, 33(5), 41-42.

Hanson, K.H., \& Hanson, K.L. (2000). Preparing for educational administration using case analysis. Upper Saddle River, NJ: Prentice Hall.

Hartzell, G. (2002). The principal's perceptions of school libraries and teacher-librarians. School Libraries Worldwide, 8(1). 92-110.

Harvey, C. A. I. (2005) Getting to Know You. School Library Journal, 51(11), 33.

Hoy, W.K. \& Tarter, C.J. (1995). Administrators solving the problems of practice: Decisionmaking concepts, cases and consequences. Needham Heights, MA: Allyn \& Bacon.

Kachel, D.E. (2003). Partners for success: A school library advocacy training program for principals. Knowledge Quest, 32(2), 17-19.

Kirschmann, R. E. (1995). Educational administration: A collection of case studies. Upper Saddle River, NJ: Prentice Hall.

Kowalski, T. J. (2001). Case studies in educational administration (3rd ed.). New York: Longman.

Kowalski, T. J. (1998). The school superintendent: Theory, practice and cases. Pearson Education POD.

Merseth, K. (1997). Cases in educational administration. New York: Longman.

Moghee, M. (2005). Helping leaders to learn: Teaching principals about school libraries. Teacher-Librarian, 32(5).

Northouse, P. G. (2001). Leadership theory and practice (2nd ed.). Thousand Oaks, CA: Sage Publications.

O'Neal, A. J. (2004). Administrators', teachers', and media specialists' perceptions of the roles of media specialists in the schools' instructional programs: Implications for instructional administration. Journal of Education for Library and Information Science, 45(4), 286-306. 
Sanders, D. (2002). A principal's perspective. Knowledge Quest, 31(2), 30-31.

Sharp, W. L. (1997). Case studies for school leaders: Implementing the ISLLC standards. Lanham, MD:Scarecrow Press.

Snowden, P. E. \& Gorton, R. A. (2002). School leadership and administration: Important concepts, case studies and simulations (6th ed.). New York: McGraw-Hill.

St. Lifer, E. (2004). Getting in the principal's face. School Library Journal, 50(10), 11.

Williams, J. L. (2006). Advocacy: The first step in achieving it all. Knowledge Quest, 34(3), 4-6.

Wilson, P. \& Blake, M. (1993). A study and a plan for partnership. Emergency Librarian, 21(1).

Wilson, P. \& MacNeil, A.J. (1998). In the dark: What's keeping principals from understanding libraries? School Library Journal, 44(9),114-116.

\section{Appendix A: Learning School Leadership Praxis through Case Studies (Abbreviated Format)

\author{
Procedures for Analyzing Case Studies \\ Prepared by Roma B. Angel
}

Step One: Read the case quickly to get an overview of the situation. Make a note of the mission facts.

Step Two: Identify, describe and analyze the perspectives/positions of the stakeholders and/or actors in the situation.

Step Three: Identify the primary problem and secondary problems. Primary problems are those that are solved to prevent the reoccurrence of other problems presented.

Step Four: Develop a list of specific, action solutions for both the primary and secondary problems.

Step Five: Evaluate the proposed/possible action solutions and select the best one(s).

Step Six: Develop an action plan with a statement of the predicted/desired outcomes.

Writing a Case Brief: Summarize the situation and the perspectives of actors, provide a statement of primary and secondary problems, provide with justification the best procedures for reaching solutions, provide an action plan with stated desired outcomes. 